\title{
Tambak-Ku: Sarana Penunjang Dalam Industri Udang Untuk Mengkuti Pekembangan Era Industri 4.0
}

\author{
Fernando Jovanca Nanda Rizky ${ }^{1}$, Raga Suhada Hari Saputra ${ }^{2}$, Hendra Supendar ${ }^{3}$ dan Imam Budiawan ${ }^{4}$ \\ ${ }^{1,2,4}$ Sekolah Tinggi Manajemen Informatika dan Komputer Nusa Mandiri \\ e-mail: ${ }^{1}$ nandojnrizky21@gmail.com, ${ }^{2}$ saputrasuhada86@gmail.com, ${ }^{4}$ imam.imb@ nusamandiri.ac.id \\ ${ }^{3}$ Universitas Bina Sarana Informatika \\ e-mail: ${ }^{3}$ hendra.hds@bsi.ac.id
}

\begin{tabular}{ccc}
\hline Diterima & Direvisi & Disetujui \\
$23-09-2020$ & $09-11-2020$ & $01-12-2020$ \\
\hline
\end{tabular}

\begin{abstract}
Abstrak - Indonesia sebagai negara kelautan memiliki garis pantai yang panjang sebesar $95.185 \mathrm{~km}$ dengan potensi lahan budidaya udang sebesar 3 juta hektar. Luas tambak udang di indonesia memiliki 300 ribu hektar dan menghasilkan satu ton udang per hektar yang dikelola oleh para nelayan. Namun, ada beberapa faktor yang membuat industri perudangan belum terimplementasi dengan optimal, kurangnya penerapan teknologi terhadap industri udang menjadi salah satu faktor terhambatnya potensi kemajuan dalam industri udang serta beberapa faktor lainnya yang didapat dari media online maupun artikel tentang permasalahan yang ada diindustri udang. Oleh karena itu, guna mengatasi maslalah tersebut dan membangun indonesia yang lebih maju, diperlukan inovasi untuk mengikuti perkembangan zaman salah satunya era industri 4.0 dengan inovasi yang digagas yaitu berupa sarana penunjang untuk industri udang dengan memanfaatkan jaringan internet dan website. Sarana yang digagas merupakan sarana yang berlingkup di industri udang, dimana sarana yang digagas tersebut adalah sebuah website yang mencangkup informasi, $e$-commerce, forum diskusi dan pengendali alat yang berbasis Internet of Things serta konsep tambak berbasis Internet of Things dan alat-alat berbasis Internet of Things yang saling behubungan dengan web di industri udang. Gagasan ini dapat membantu para stakeholder yang ada diindustri udang dalam mengatasi beberapa masalah yang ada di industri udang.
\end{abstract}

Kata Kunci: Web, Internet Of Things, Konsep

Abstract - Indonesia as a maritime country has a long coastline of 95,185 $\mathrm{km}$ with a capacity of shrimp cultivation of 3 million hectares. The area of shrimp ponds in Indonesia has 300 thousand hectares, and produces one ton of shrimp per hectare which is managed by fishermen. Also, there are several factors that have made the warehousing trade not yet implemented optimally, and the lack of application of technology to the shrimp trade is one of the factors interfering the potential for progress in the shrimp industry as well as several other factors collected from online media and articles about issues in the shrimp trade. Thus, in order to conquer this situation and create a more progressive in Indonesia, the invention is needed to keep up with the times one of which is the industrial era 4.0 with inventions begun in the form of supporting facilities for the shrimp trade by using the internet and website networks. The facility that was inaugurated is a facility which is covered in the shrimp trade, where the facility that was inaugurated is a website that includes information, e-commerce, discussion forums and tool controllers based on the Internet of things and the concept of an Internet-based pond of things and Internet-based tools of things that are interconnected with the web in the shrimp trade. This idea can help stakeholders in the shrimp trade in conquering some of the issues that exist in the shrimp industry.

Keywords: Web, Internet of Things, Concept

\section{PENDAHULUAN}

Indonesia sebagai negara kelautan memiliki garis pantai yang panjang sebesar $95.185 \mathrm{~km}$ dengan potensi lahan budidaya udang sebesar 3 juta hektar (Reily, 2018). Luas tambak udang di indonesia memiliki 300 ribu hektar, dan menghasilkan satu ton udang per hektar yang dikelola oleh para nelayan. (Yunianto, 2019). Namun, ada beberapa faktor yang membuat industri perudangan belum terimplementasi dengan optimal sehingga menyebabkan kesulitannya mendapatkan sarana produksi udang dan kurangnya penerapan teknologi terhadap industri udang menjadi salah satu faktor terhambatnya potensi kemajuan dalam industri udang. Untuk membangun indonesia yang lebih maju, diperlukan sinergi antara para stakeholder seperti : Pemerintah, swasta (dunia 
usaha) dan masyarakat harus saling bekerja sama agar dapat membangun indonesia menjadi lebih baik lagi. (Arviana, 2016).

Sekitar $80 \%$ dari entitas budidaya perairan di Indonesia masih menjalankan praktik pertanian tradisional atau ekstensif bahkan hingga tahun lalu, data tersebut didapat dari Badan Pusat Statistik (BPS), Menurut Badan Pusat Statistik (BPS), agar budidaya perairan tetap kompetitif, budidaya perairan di Indonesia harus mengadopsi peralatan dan teknik produksi yang lebih modern. Namun, hal ini masih memiliki kendala karena mayoritas pelaku budidaya perairan terdiri dari industri rumah tangga yang memiliki modal yang minim bahkan tidak ada modal serta kurangnya keterampilan yang cukup untuk memodernisasi teknik pertanian (Nurfitriyani, 2015).

Dari artikel atau beberapa media online penulis menemukan beberapa kasus yang perlu untuk dipecahkan dengan sebuah inovasi. Penulis menemukan adanya kesulitan para petani atau pembudidaya untuk mendapatkan benih dan indukan, mencari bantuan modal, selain itu sarana produksi tambak didaerah terkadang sulit didapatkan dan kurangnya integrasi antara pemroses di hilir dan petambak di hulu. Petambak juga mengalami kesulitan dalam memperoleh informasi baik update teknologi maupun permasalahan dalam budidaya udang serta kurangnya penerapan teknologi menjadi salah satu faktornya.

Berdasarkan hal tersebut penulis memiliki gagasan yaitu berupa inovasi pada industri tambak udang atau budidaya udang kearah industri yang mengikuti perkembangan era industri 4.0. Gagasan ini dinamakan "TAMBAK-KU:Sarana Penunjang Dalam Industri Udang Untuk Mengikuti Perkembangan Era Industri 4.0" merupakan gagasan dengan menambah sebuah program untuk Kementrian Kelautan dan Perikanan (KKP) dimana, proses yang berhubungan tentang industri tambak udang dituangkan ke dalam sebuah platform seperti penjualan maupun pembelian, sarana berkomunikasi maupun menyebarkan informasi, serta pengontrolan maupun rancangan sarana yang dikendalikan secara jarak jauh dengan menggunakan fasilitas internet yang dikelola oleh Kementrian Kelautan dan Perikanan (KKP).

\section{METODE PENELITIAN}

Penulis menggunakan sebuah metode penelitian, yaitu Teknik Pengumpulan Data. Teknik Pengumpulan Data yang digunakan ialah observasi yaitu dengan melihat, mencari permasalahan yang ada di industri udang melalui internet terutama artikel atau berita terkait maupun sosial media, dan studi pustaka yaitu dengan mengumpulkan informasi melalui buku - buku ataupun jurnal terkait pada penulisan ini.

\section{HASIL DAN PEMBAHASAN}

\section{Kondisi Terkini}

Pertumbuhan komoditas perikanan indonesia saat ini mengalami peningkatan dan kemajuan yang baik. Salah satu komoditas unggulan perikanan yaitu adalah udang. Dalam lima tahun terakhir perkembangan volume produksi udang nasional memperlihatkan tren pertumbuhan yang positif dengan pertumbuhan rata-rata per tahun sebesar 15,7 persen (Sagita, 2018). Saat ini jumlah produksi udang nasional sebesar 200 ribu ton per tahun dan didorong menjadi 500 ribu ton di tahun depan (Yunianto, 2019). Hal ini pun juga berpengaruh terhadap nilai ekspor udang jika produksi udang nasional meningkat, seperti data dari Kementrian Kelautan dan Perikanan (KKP) dan comtrade.un.org menunjukkan setiap tahunnya volume dan nilai ekspor udang mengalami kenaikan walaupun hanya sedikit.

Tabel 1. Volume dan Nilai Ekspor Udang 2015-Juni 2019.

\begin{tabular}{|l|l|l|l|}
\hline No. & Tahun & Volume & Nilai \\
\hline 1 & 2015 & 152.677 & 1,4 Milliar US\$ \\
\hline 2 & 2016 & 164.308 & 1,5 Milliar US\$ \\
\hline 3 & 2017 & 169.197 & 1,7 Milliar US\$ \\
\hline 4 & 2018 & 172.899 & 1,6 Milliar US\$ \\
\hline
\end{tabular}

Sumber : Kementrian Kelautan dan Perikanan (KKP), comtrade.un.org dilansir oleh https://databoks.katadata.co.id/datapublish/2019/12/16/tar get-naik-250-pada-2024-berapa-nilai-dan-volume-eksporudang

Pada tahun 2024 Kementerian Kelautan dan Perikanan (KKP) menargetkan peningkatan nilai ekspor udang mencapai $250 \%$. Peningkatan tersebut memiliki dua kali lipat target peningkatan setiap tahunnya (Jayani, 2019b). Disamping pertumbuhan komoditas perikanan Indonesia mengalami kemajuan. Namun, masih masih ada beberapa faktor yang menghambat proses peningkatan tersebut dalam industri udang di indonesia. Ada tiga faktor utama yang menghambat potensi laju industri udang. Perusahaan riset pasar independen yang berada di Hong Kong yaitu Ipsos, mencatat ketiga faktor tersebut, seperti rendahnya penerapan teknologi, minim dan tidak meratanya pembangunan infrastruktur yang berada di berbagai sentra tambak udang dan integrasi antara stakeholder industri udang seperti, pemrosesan di hilir dan petambak di hulu yang sangat minim (Nurfitriyani, 2015). Selain itu terdapat juga faktor lain seperti, sulitnya mendapatkan sarana produksi, serangan penyakit juga masih menghantui kegiatan budi daya udang nasional, permasalahan kurangnya benih dan indukan dan kesulitan untuk mengakses permodalan maupun 
mencari tambahan modal. Saat ini, pemerintah Indonesia sedang mendorong peningkatan produksi udang secara nasional pada 2020 yang dilaksanakan di berbagai daerah. Untuk melaksanakan target tersebut, beragam cara mulai dilaksanakan Pemerintah melalui berbagai program dengan mendorong pengembangan budi daya tambak udang di Indonesia melalui beragam teknologi (Ambari, 2020).

Dengan perkembangan dunia internet yang sangat signifikan ini dan juga dengan dimasukannya teknnologi internet yang dijadikan di dalam sebuah pengetahuan telah menjadikan banyak keuntungan bagi semua pihak yang menggunakan internet (Anam, 2019). Internet di masyarakat bukan lagi hal yang baru dan bukan milik segelintir orang saja, tetapi internet dan manfaat internet telah dirasakan masyarakat dari berbagai aspek kehidupan sehari-hari (Mughni, 2016). Penggunaan internet seiring berjalanya waktu semakin tinggi, termasuk di Indonesia. Di Indonesia, internet sudah masuk ke hampir seluruh pelosok desa. Semua sektor kehidupan manusia saat ini hampir dapat dipastikan terkait dengan internet. Pada sektor ekonomi, politik, sosial, budaya, agama, dan pendidikan, internet sudah digunakan untuk fasilitasi kegiatannya (Yusup, Komariah, Prahatmaja, \& CMS, 2019). Data Statista 2019 menunjukkan pengguna internet di Indonesia pada 2018 sebanyak 95,2 juta, tumbuh 13,3\% dari 2017 yang sebanyak 84 juta pengguna (Jayani, 2019a).

Tabel 2. Pengguna Internet di Indonesia

\begin{tabular}{|c|c|c|}
\hline No & Tahun & Pengguna \\
\hline 1 & 2017 & 84 Juta \\
\hline 2 & 2018 & 95,2 Juta \\
\hline 3 & 2019 & 107,2 Juta \\
\hline
\end{tabular}

Sumber : Statista, dilansir oleh
https://databoks.katadata.co.id/datapublish/2019/09/09/ber apa-pengguna-internet-di-indonesia

Penggunaan internet terutama digunakan untuk sistem industri 4.0. Industri 4.0 merupakan istilah yang sudah tidak asing lagi bagi masyarakat saat ini. Industri 4.0 adalah istilah yang saat ini umum digunakan untuk revolusi industri ke-4 (alamsyah, 2018). Kemajuan teknologi yang menghubungkan serta mengintegrasikan antara dunia fisik, dengan digital dan biologis merupakan sebuah revolusi industri 4.0 dimana terdapat perubahan dalam cara hidup kerja manusia (Hamdan, 2018). Perkembangan teknologi dan informasi kususnya di indonesia memiliki peningkatan yang cukup pesat. Dampak era revolusi industri 4.0 ini tentu sangat besar bagi dunia industri maupun juga perilaku di masyarakat dalam kegiatan industri maupun kegiatan transaksi. Revolusi industri 4.0 bahkan diyakini dapat meningkatkan perekonomian dan kualitas kehidupan secara signifikan (Baenanda, 2019). Revolusi industri
4.0 ditandai dengan peningkatan digitalisasi manufaktur yang didorong oleh beberapa faktor di bawah ini (Maulina, 2019) :

1. Peningkatan volume data, kekuatan komputasi, dan konektivitas.

2. Munculnya analisis, kemampuan, dan kecerdasan bisnis.

3. Terjadinya bentuk interaksi baru antara manusia dengan mesin.

Berdasarkan hasil self-assessment yang dilakukan oleh andrea lidwina, rata-rata indeks kesiapan industri manufaktur Indonesia ada di level 2,14 atau dinilai cukup siap. Dengan rincian 1,95 teknologi, 2,06 operasi pabrik, 2,12 manajemen dan organisasi, 2,16 orang dan budaya, 2,41 produk dan layanan (Lidwina, 2019).

Salah satu sarana agar dapat mengikuti era industri 4.0 yaitu dengan industri digital. Komoditi industri digital sudah sangat memberikan pengaruh yang sangat besar bagi laju pasar ekonomi kelas menengah kebawah, dengan hadirnya industrialisasi teknologi sudah tidak ada alasan bagi siapapun yang akan memulai usaha dalam bidang apapun, dengan memberikan warna baru untuk percepatan ekonomi khusunya di kawasan pedesaan (Kristian, 2019). Saat ini penerapan industri 4.0 diindustri udang masih kurang penerapannya sehingga praktik industri petani atau pembudidaya udang masih secara tradisional. Media industri 4.0 yang dapat digunakan para petani atau pembudidaya udang yaitu melalui teknologi web. Web adalah jaringan komputer yang terdiri dari kumpulan sius internet yang menawarkan teks dan grafik dan suara dan sumber daya animasi melalui hypertext transfer protocol (Rerung, 2018). Dengan adanya web pengguna dapat menampilkan sebuah halaman virtual yang biasa disebut dengan website.

Website merupakan sarana indsutri 4.0 yang sangat mudah untuk digunakan. Website adalah kumpulan informasi/kumpulan page yang biasa diaskes lewat jalur internet. Sekumpulan halaman yang terdiri dari beberapa laman yang berisi informasi dalam bentuk data digital baik berupa text, gambar, video, audio, dan animasi lainnya merupakan definisi website atau disingkat web (Junirianto, 2018). Internet sangat berpengaruh dalam cara bisnis pada era industri 4.0. Website sangat mudah dikarenakan tidak perlu untuk melakukan instalasi pada perangkat dan menggunakan spesifikasi perangkat yang memadai hanya dengan membuka web browser yang ada diperangkat dan langsung mengetikkan domain saja, pengguna dapat langsung mengakses website tersebut. Sistem jual beli secara online menjadi salah satu sarana yang paling banyak diakses oleh siapa pun. 
Dengan adanya internet saat ini sangat bermanfaat dalam cara masyarakat berkomunikasi maupun bersosialisasi, dengan adanya internet membuat komunikasi dapat dilakukan secara online tanpa harus bertatap muka. Cara komunikasi yang semakin modern membuat penyampaian informasi maupun berkomunikasi sangat mudah. Salah satu cara berkomunikasi secara online yaitu melalui media jejaring sosial. Perusahaan riset yang bermarkas di London, yaitu GlobalWebIndex menganalisa data dari 45 pasar di internet dan memperkirakan bahwa waktu yang digunakan setiap orang untuk media sosial meningkat dari awalnya 90 menit/hari pada tahun 2012 menjadi 143 menit/hari pada tiga bulan pertama tahun 2019 (Duarte, 2019). Berdasarkan hasil riset Wearesosial Hootsuite yang dirilis pada bulan Januari 2019 pengguna media sosial khususnya di Indonesia mencapai 150 juta atau sebesar 56\% dari total populasi. Jumlah tersebut mengalami kenaikan sebesar $20 \%$ dari survei sebelumnya. Sedangkan pengguna media sosial mobile (gadget) mencapai 130 juta atau sekitar $48 \%$ dari populasi (Katadata.co.id, 2019).

Tabel 3. Data Pengguna Telepon, Internet, Media Sosial Indonesia

\begin{tabular}{|c|c|c|}
\hline No & Pengguna & Juta Pengguna \\
\hline 1 & Telepon & 355,5 \\
\hline 2 & Internet & 150 \\
\hline 3 & $\begin{array}{c}\text { Aktif Media } \\
\text { Sosial }\end{array}$ \\
\hline Sumber : & We Are Social, dilansir oleh
\end{tabular}
https://databoks.katadata.co.id/datapublish/2019/02/08/ber apa-pengguna-media-sosial-indonesia

Dampak internet saat ini juga berpengaruh terhadap kemajuan teknologi yang ada. Penerapan teknologi seperti sistem pengendali jarak jauh dengan menggunakan jaringan internet sangat berguna dalam industri 4.0 pada saat ini. Di industri tambak udang saat ini masih minim dalam penggunaan sistem pengendali jarak jauh. Penerapan teknologi semacam ini sangat membantu kerja manusia dalam melakukan kegiatan kapanpun dan dimanapun selagi masih terhubung dengan jaringan internet, sarana yang digunakan dapat dikendalikan secara jarak jauh tanpa adanya kontak langsung antara manusia dan mesin dengan menggunakan sebuah perantara alat elektronik yang menggunakan jaringan internet. Dengan adanya gagasan platform online, konsep tambak yang lebih modern dan alat - alat berbasis Internet of Things di industri udang ini sebagai upaya untuk dapat menerapkan teknologi di industri udang yang saat ini minim penerapannya. Serta inovasi untuk mengikuti era industri 4.0 agar dapat mempermudah para petani tambak atau pembudidaya udang dalam industri udang dan menjadi salah satu sarana penunjang dalam industri udang sehingga berpengaruh terhadap nilai produksi udang untuk nasional maupun untuk ekspor di masa yang akan datang.

\section{Solusi Yang Pernah Diterapkan}

A. eFishery

adalah sebuah perangkat yang diciptakan oleh Gibran Huzaifah untuk memberi makan ikan secara otomatis tanpa perlu takut memberi pakan terlalu banyak atau terlalu sedikit.

B. Teknologi Microbubble Dengan Integrasi Teknologi Recirculating Aquaculture System. adalah teknologi proses budidaya yang tidak memerlukan lagi penyifonan, yaitu proses pembuangan lumpur limbah sisa pakan dan kotoran udang. Sebagai gantinya, limbah padatan pada sistem ini akan ditangkap pada penyaring fisik dan akan dimanfaatkan untuk pupuk tanaman. (Ambari, 2019).

\section{Splash Aerator Energi Angin}

adalah alat yang di rekayasa oleh tiga dosen Fakultas Teknik yakni: Dr.Muhammad Alfian Mizar, M.P, Dr. Eng. Mochamad Sholihul Hadi, S.T, M.Eng., dan Prof. Dr. Marji, M.Kes, yang dirancang untuk mentransfer oksigen ke dalam air tambak. Sehingga berpengaruh tehadap air tambak yang dapat memenuhi syarat optimum kebutuhan oksigen dalam budidaya udang (Budiharto, 2019).

\section{Kondisi Gagasan Yang Diajukan}

\section{A. E-Commerce}

E-commerce merupakan teknologi yang menjadi kebutuhan mendasar setiap organisasi yang bergerak di bidang perdagangan (Mumtahana, Hani Atun, Nita \& Tito, 2017). E-commerce adalah kegiatan-kegiatan bisnis dengan tujuan mengambil keuntungan seperti penjual, pembelian, pelayanan, informasi, dan perdagangan melalui perantara yaitu melalui suau jaringan komputer, terutama internet (Romindo \& et al., 2019). Dengan adanya $e$ commerce merupakan alternatif bisnis yang cukup menjanjikan. E-commerce dapat memberikan banyak kemudahan bagi pihak penjual maupun dari pihak pembeli dalam melakukan transaksi. (Aco \& Endang, 2017). Saat ini e-commerce merupakan salah satu jenis platform yang sering diakses atau dikunjungi oleh masyarakat indonesia. Hasil studi yang dikeluakan oleh Portal diskon CupoNation, yaitu tentang toko daring yang paling banyak dikunjungi oleh masyarakat indonesia selama 6 bulan terakhir. Periode riset dilakukan mulai Januari-Juni 2019. Hasil dalam riset tersebut, mendapati tokopedia merupakan platform yang paling banyak dikunjungi yaitu sebanyak 805,5 juta kunjungan. Bukalapak yang berada di posisi kedua dengan jumlah 588,3 juta kunjungan. Sedangkan shopee yang berada di peringkat ketiga dengan total 476,5 juta kunjungan (Mudassir, n.d.). Dengan, perkembangan e-commerce yang semakin pesat. salah satu inovasi dalam industri udang yaitu situs $e$ commerce yang dikhususkan untuk industri udang. 
Namun, meskipun mengalami kemajuan $e$ commerce yang pesat kendala para petani atau pembudidaya udang yang mengalami kesulitan untuk mencari barang - barang kebutuhan proses produksi di platform tersebut belum teratasi, dikarenakan barang - barang kebutuhan produksi khususnya di bidang industri udang terkadang sulit dicari di sebuah situs jual beli online dan tidak banyak yang beredar di pasaran karena kebutuhan produksi diciptakan oleh bidang usaha UMKM (Usaha Micro, Kecil, Menengah), serta dengan tidak adanya kebijakan dari platform tersebut. Jika terdapat kebutuhan produksi udang, siapa pun dapat menjual barangnya meskipun sudah ada merek yang telah ada di katalog dan hanya dibedakan oleh harga yang bervariatif. Maka dari itu dengan kondisi gagasan tersebut penulis membuat sebuah konsep perubahan atau pembaruan dalam sarana jual beli online yang ada di industri udang dengan membuat sebuah web e-commerce khusus menjual kebutuhan yang ada di industri udang dan petani atau pembudidaya udang dapat menjual hasil panennya melalui web e-commerce ini.

\section{B. Forum Diskusi}

Perkembangan teknologi komunikasi yang sangat pesat menjadikan masyarakat dunia telah bergerak dan beralih dari era tradisional, industrialisasi ke era informasi yang berujung pada hadirnya masyarakat informasi (information society) (Ahmad, 2013). Media baru adalah konsep yang menjelaskan kemampuan media yang dengan dukungan perangkat digital dapat mengakses konten kapan saja, dimana saja sehingga memberikan kesempatan bagi siapa saja baik sebagai penerima/pengguna untuk berpartisipasi aktif, interaktif, dan kreatif terhadap umpan balik pesan yang pada gilirannya membentuk komunitas/masyarakat baru melalui isi media (Liliweri, 2017). Media sosial/ social media atau yang dikenal juga dengan jejaring sosial merupakan bagian dari media baru (Watie, 2016). Saat ini teknologi informasi dan komunikasi berkembang dengan cepat, sarana untuk penyampaian informasi pun beragam dan membuat cara berkomunikasi masyarakat di era modern ini mengalami perubahan. Salah satu inovasi berikutnya dalam industri udang yaitu dengan adanya sebuah platform forum atau sarana bertukar informasi maupun pikiran serta berkomunikasi yang dikhususkan untuk industri udang.

\section{Internet Of Things}

Perkembangan kemajuan teknologi saat ini sudah sangat berkembang dengan pesat, tidak dapat dipungkiri kemajuan teknologi yang sedemikian cepat harus bisa dimanfaatkan, dipelajari serta diterapkan dalam kehidupan sehari hari. Salah satu kemajuan yang bisa dirasakan adalah di bidang kendali (Ma'mur \& Mubarokallah, 2018). Internet of Things merupakan salah satu cara di bidang kendali. Menurut (Hardana \& Isputra, 2019) Internet of Things adalah suatu cara untuk menghubungkan perangkat elektronik ke internet dan mengontrolnya dari seluruh dunia selama 24 jam non stop. Pada tahun 2019, produk hasil IoT sudah mulai berkembang. Dengan adanya IoT diharapkan mampu untuk mengumpulkan informasi secara realtime dengan menghubungkan mesin yang dapat memproduksi data dengan memanfaatkan sensor, dalam perangkat ponsel maupun perangkat pintar lainnya (Aidiem, 2019). Salah satu inovasi berikutnya dalam industri udang yaitu dengan adanya sebuah penerapan teknologi berupa konsep tambak udang menggunakan alat yang berbasis Internet Of Things dan dapat dikendalikan secara jarak jauh sehingga dapat membantu para petani dan pembudidaya udang dalam melakukan proses produksi udang, teknologi ini berbasis Internet $O f$ Things dimana internet sebagai penghubung dari sarana produksi udang yang ada dan dikhususkan untuk industri udang.

\section{Pihak Yang Dipertimbangkan \\ A. Pemerintah}

Peran pemerintah daerah sangat penting guna membangun sarana infrastruktur didaerah industri udang yang saat ini masih kurang memadai, peran Kementrian Kelautan dan Perikanan pun juga penting untuk mendukung penerapan teknologi guna meningkatkan hasil produksi dalam negeri yang akan berpengaruh terhadap nilai maupun volume ekspor udang dan melakukan monitoring terhadap perkembangan industri udang serta mendukung penerapan proses industri kearah yang lebih modern.

\section{B. Perusahaan dan UMKM (Usaha Micro, Kecil,} Menengah).

Peran perusahaan juga sangat dipertimbangkan terutama perusahaan pembuat sarana produksi udang dalam upaya para petani atau pembudidaya udang untuk mendapatkan sarana produksi yang mudah, harga yang transparan dan juga berkualitas serta menerapkan alat yang berbasis IoT, peran UMKM (Usaha Micro, Kecil, Menengah) juga patut dipertimbangkan, agar dapat pula membantu para pelaku UMKM (Usaha Micro, Kecil, Menengah) berkembang dan dapat pula membantu para petani atau pembudidaya untuk mencari kebutuhan yang murah namun tetap berkualitas, peran perusahaan pendanaan untuk membantu para petani atau pembudidaya udang yang mengalami kesulitan dalam hal finansial dapat terbantu dengan perusahaan ini dengan bantuan modal untuk membangun sebuah usaha dalam industri udang dengan kerja sama yang saling menguntungkan kedaua belah pihak dan peran perusahaan provider internet yang sangat penting dalam gagasan ini, karena gagasan ini membutuhkan jaringan internet sebagai peran utama dalam menerapkan gagasan ini serta peran perusahaan listrik milik negara atau biasa dikenal dengan PT.PLN 
sangat penting pula. Karena gagasan ini, masih menggunakan sumber daya listrik dari PT.PLN dan belum menggunakan pembangkit listrik alternatif sendiri sebagai sumber daya listriknya.

\section{Masyarakat}

Peran masyarakat dapat membantu dalam industri udang dengan kegiatan pembelian hasil produksi, jika masyarakat maupun dari kalangan mahasiswa yang memiliki ide dapat memberikan masukkan atau inovasinya maupun melakukan pengembangan dengan teknologi yang sudah ada terkait industri udang untuk bisa diterapkan di masa yang akan datang. Lebih baik lagi jika, memiliki konsep yang lebih efektif ataupun lebih modern dari gagasan yang penulis buat.

\section{IT Developer}

Peran IT Developer sangat dibutuhkan, karena implementasi ini membutuhkan orang yang dapat membantu dalam pembuatan platform dan membantu perusahaan dalam pembuatan alat berbasis IoT maupun melakukan evaluasi jika gagasan ini diimplementasikan. Evaluasi ini agar gagasan yang diajukan dapat dikembangkan ataupun diperbaiki lagi dikemudian hari.

\section{Langkah - Langkah Strategis \\ A. Tahap 1}

Memberitahukan ide gagasan kepada pemerintah daerah maupun Kementrian Kelautan dan Perikanan agar dapat mendukung gagasan ini di implementasikan.

\section{B. Tahap 2}

Memberikan masukan terhadap pemerintah khusunya pemerintah daerah agar dapat membantu dalam menerapkan gagasan ini dengan memperbaiki infrastruktur, diharapkan dengan memperbaiki infrastruktur dapat mempermudah dalam menerapkan gagasan ini.

\section{Tahap 3}

Memberitahukan ide gagasan kepada produsen sarana produksi dan khusus produsen sarana produksi untuk alat agar dapat menjadi rekomendasi pada sistem produksi yang baru.

\section{Tahap 4}

Mengembangkan kerja sama dengan pihak pihak yang dipertimbangkan seperti perusahaan pembuat sarana produksi budidaya udang, perusahaan pendanaan, perusahaan listrik milik negara, perusahaan provider internet, serta para IT Developer, yang akan dapat membantu dalam pengerjaan gagasan ini. Diperlukan pula kerja sama yang baik antara pihak-pihak yang berhubungan dengan industri udang agar penerapannya mendapat hasil yang maksimal. Kerja sama yang dimaksud dapat berupa konsultasi, kerja sama dalam pengerjaan maupun penyampaian informasi.

\section{E. Tahap 5}

Menggerakkan pihak-pihak yang terlibat dalam melaksanakan gagasan ini. Seperti pemerintah, perusahaan masyarakat maupun stakeholder yang ada di industi udang.

\section{F. Tahap 6}

Memberikan informasi kepada para petani atau pembudidaya udang serta masyarakat dengan rencana gagasan inovasi ini.

\section{G. Tahap 7}

Proses implementasi gagasan

\section{H. Tahap 8}

Melakukan evaluasi dan monitoring. Kendala serta pengalaman yang ada dalam membuat dan penggunaan program ini, agar dapat menjadi pembelajaran dari model atau sistem untuk kedepannya.

\section{Gagasan yang Diajukan}

Gagasan yang diajukan berupa program yang dikelola atau dibawah pengawasan oleh Kementrian Kelautan dan Perikanan untuk stakeholder yang ada di industri udang dalam rangka mengikuti perkembangan era industri 4.0 dan sebagai sarana penunjang dalam industri udang dengan beberapa konsep yang ada di dalam program tersebut, yaitu: 1. Sebuah web yang berlingkup di industri udang. Web ini akan menjadi platform untuk industrri udang, dimana web tersebut memiliki sistem informasi yang berkaitan dengan industri udang serta memiliki beberapa menu atau fitur sebagai sarana penunjang dalam industri udang

2. Menu e-commerce khusus industri udang. $E$ commerce merupakan salah satu konsep penjualan yang saat ini banyak digunakan oleh masyarakat Indonesia, gagasan yang penulis buat adalah membuat sebuah konsep e-commerce dengan pihak yang diterkait di industri udang dan bersifat khusus untuk industri udang.

3. Menu forum diskusi khusus industri udang. Sosial media saat ini memiliki beragam jenis model untuk dapat menghubungkan para pengguna dengan dunia luar maupun berkomunikasi secara online sesame pengguna, gagasan yang penulis buat adalah membuat sebuah konsep forum diskusi bersifat khusus untuk industri udang dalam mencari infromasi, bertukar pikian dan berkomunikasi .

4. Konsep lahan tambak berbasis IoT. Konsep ini merupakan gagasan penulis untuk dapat mengelola lahan tambak dengan menggunakan internet sebagai penghubung antara alat dan manusia melalui website. 5. Alat industri udang berbasis IoT beserta menu web untuk pengendali alat industri udang berbasis IoT. Alat-alat didalam industri udang ini akan berhubungan dengan konsep lahan tambak berbasis IoT yang penulis buat dan web yang digagas oleh penulis. 


\section{Kesimpulan}

1. Gagasan yang dibuat merupakan inovasi dan sebagai sarana peununjang pada industri tambak udang atau budidaya udang kearah industri yang mengikuti perkembangan era industri 4.0 dengan menggunakan sebuah platform online.

2. Gagasan yang dibuat memiliki sebuah web yang berlingkup diindustrri udang dan menjadi wadah dalam industri udang. Dimana terdapat sistem inforrmasi, e-commerce, forum diskusi, dan web pengendalian alat ioT yang dapat pula sebagai monitoring tambak berbasis IoT.

3. Gagasan yang dibuat merupakan langkah perubahan proses yang ada diindustri udang untuk mengarahkan ke industri yang berbasis digital baik dari penjualan atau pembelian, berkomunikasi antar stakeholder, maupun pengendalian alat tambak dan monitoring tambak..

4. Gagasan yang dibuat memiliki konsep lahan tambak berbasis IoT dan alat-alat berrbasis IoT.

5. Gagasan yang dibuat merupakan gagasan untuk petani tambak atau pembudidaya udang dalam mempermudah berindustri udang dan meningkatkan nilai produksi udang melalui program pemerintah.

6. Pengajuan modal yang diberikan oleh pihak perusahaan pendanaan berbentuk berupa alat, sehingga akan diberikan kepada pengaju berupa alat yang diajukan, bukan pengajuan berbentuk modal uang.

7. Beberapa alat yang digagas meupakan ide dari penulis agar dapat berhubungan dengan konsep tambak bebasis IoT dan web yang digagas.

8. Alat-alat yang digagas menggunakan board arduino yang sudah terdapat modul ESP 8266.

9. Beberapa alat yang digagas masih membutuhkan manusia untuk menggerakkannya (belum otomatis) melalui web. Hal ini dikarenakan penulis ingin meminimaslir jika terjadi kendala pada alat, pengguna dapat mengetahuinnya secara langsung.

\section{Referensi}

Aco, A., \& Endang, A. H. (2017). Analisis Bisnis ECommerce pada Mahasiswa Universitas Islam Negeri Alauddin Makassar. Jurnal Insypro, 2, $1-13$.

Ahmad, A. (2013). Perkembangan Media Online dan Fenomena Disinformasi ( Analisis pada
Sejumlah Situs Islam ) Online Media Development and Phenomenon of Disinformation ( Analysis of Islamic sites ). Jurnal Pekommas, 16(3), 177-186.

Aidiem. (2019). Bagaimana Perkembangan IoT di Tahun 2020? Halaman 1 - Kompasiana.com. https://www.kompasiana.com/idmetafora/5c91 de4e3ba7f707c618c112/bagaimanaperkembangan-iot-di-tahun-2020

Alamsyah, R. (2018). Analisis dampak industri 4.0 terhadap sistem pengawasan ketenaganukliran di indonesia. Jurnal Forum Nuklir (Jfn), 12, 47-54.

Ambari, M. (2019). Microbubble: Teknologi Baru Ramah Lingkungan untuk Budidaya Udang: Mongabay.co.id.

https://www.mongabay.co.id/2019/01/08/micr obubble-teknologi-baru-ramah-lingkunganuntuk-budidaya-udang/

Ambari, M. (2020). Sistem Klaster, Teknologi Ramah Lingkungan pada Budi daya Udang: Mongabay.co.id.

https://www.mongabay.co.id/2020/02/17/siste m-klaster-teknologi-ramah-lingkungan-padabudi-daya-udang/

Anam, M. K. (2019). Perkembangan Web dan Inovasi Tentang Industri 4.0 dan Society 5.0. https://medium.com/@muhammad.1384/perke mbangan-web-dan-inovasi-tentang-industri-40-dan-society-5-0-3948b2f834b3

Arviana, N. (2016). Pentingnya Sinergi Stakeholder dalam Meningkatkan Perekonomian SWA.co.id.

https://swa.co.id/swa/trends/economicissues/pentingnya-sinergi-stakeholder-dalammeningkatkan-perekonomian

Baenanda, L. (2019). Mengenal lebih jauh Revolusi Industri $4.0 \quad-\quad$ BINUS University. https://binus.ac.id/knowledge/2019/05/mengen al-lebih-jauh-revolusi-industri-4-0/

Budiharto. (2019). LP2M Terapkan Hasil Inovasi Teknologi Tambak Udang | Universitas Negeri Malang (UM). https://um.ac.id/berita/lp2mterapkan-hasil-inovasi-teknologi-tambakudang/

Duarte, F. (2019). Berapa banyak waktu yang dihabiskan rakyat Indonesia di media sosial? BBC News Indonesia. https://www.bbc.com/indonesia/majalah49630216

Hamdan, H. (2018). Industri 4.0: Pengaruh Revolusi Industri Pada Kewirausahaan Demi Kemandirian Ekonomi. Jurnal Nusantara Aplikasi Manajemen Bisnis, 3(2), 1. ISSN: 2549-5291. https://doi.org/10.29407/nusamba.v3i2.12142

Hardana, \& Isputra, R. F. (2019). Membuat Aplikasi IoT: INTERNET OF THINGS (L. Hakim, Ed.). Yogyakarta: Lokomedia. ISBN: 978-6026231-24-6 
Jayani, D. H. (2019a). Berapa Pengguna Internet di Indonesia? https://databoks.katadata.co.id/datapublish/201 9/09/09/berapa-pengguna-internet-diindonesia

Jayani, D. H. (2019b). Target Naik 250\% pada 2024, Berapa Nilai dan Volume Ekspor Udang? | Databoks.

https://databoks.katadata.co.id/datapublish/20 19/12/16/target-naik-250-pada-2024-berapanilai-dan-volume-ekspor-udang

Junirianto, E. (2018). PEMROGRAMAN WEB DENGAN FRAMEWORK LARAVEL (1st ed.; T. W. Publish, Ed.). ISBN: 978-623-7007-104.

Katadata.co.id. (2019). Berapa Pengguna Media Sosial Indonesia? | Databoks. https://databoks.katadata.co.id/datapublish/201 9/02/08/berapa-pengguna-media-sosialindonesia

Kristian, W. (2019). Manfaat Serta Prinsip Era Industri 4.0 yang Wajib Milenial Ketahui. https://sis.binus.ac.id/2019/09/12/manfaatserta-prinsip-era-industri-4-0-yang-wajibmilenial-ketahui/

Lidwina, A. (2019). Kesiapan Indonesia Hadapi Era Industri 4.0 - Infografik Katadata.co.id. https://katadata.co.id/infografik/2019/10/12/ke siapan-indonesia-hadapi-era-industri-40

Liliweri, A. (2017). Komunikasi Antar-Personal (1st ed.). Jakarta: Kencana Prenada Media Group. ISBN: 978-6021-1864-35.

Ma'mur, M., \& Mubarokallah, K. Al. (2018). Sistem Kendali Lampu Jarak Jauh Berbasis Web. Jurnal Cendikia, 16(2), 140-145. ISSN: 02169436.

https://jurnal.dcc.ac.id/index.php/JC/article/vie w/114

Maulina, R. (2019). Peluang Bisnis Baru di Era Revolusi Industri 4.0 - Jurnal Blog. https://www.jurnal.id/id/blog/peluang-bisnisbaru-di-era-revolusi-industri-4-0/

Mudassir, R. (n.d.). Ini 10 e-Commerce yang Paling Banyak Dikunjungi di Indonesia - Teknologi Bisnis.com.

https://teknologi.bisnis.com/read/20190809/84 /1134495/ini-10-e-commerce-yang-palingbanyak-dikunjungi-di-indonesia

Mughni, A. (2016). Dampak Positif Internet dalam Kehidupan Masyarakat Pengertian, Internet berasal dari bahasa Inggris, "International Networking”, yaitu dua komputer atau lebih yang saling berhubungan. https://sulselprov.go.id/welcome/post/dampakpositif-internet-dalam-kehidupan-masyarakat
Mumtahana, Hani Atun, Nita, S., \& Tito, A. W. (2017). khazanah informatika Pemanfaatan Web E-Commerce untuk Meningkatkan Strategi Pemasaran. Pemanfaatan Web ECommerce Untuk Meningkatkan Strategi Pemasaran, 3(1), 6-15. http://journals.ums.ac.id/index.php/khif/article /view/3309/2784

Nurfitriyani, A. (2015). Ini Masalah Besar yang Dihadapi Industri Udang Indonesia. https://www.wartaekonomi.co.id/read77215/in i-masalah-besar-yang-dihadapi-industriudang-

indonesiahttps://www.wartaekonomi.co.id/rea d77215/ini-masalah-besar-yang-dihadapiindustri-udang-indonesia

Reily, M. (2018). Indonesia Berpotensi Jadi Eksportir Udang Terbesar Dunia - Berita Katadata.co.id. https://katadata.co.id/berita/2018/03/28/indone sia-berpotensi-jadi-eksportir-udang-terbesardunia

Rerung, R. R. (2018). Pemrograman Web Dasar (1st ed.). ISBN: 978-602-43-744-9.

Romindo, \& et al. (2019). E-Commerce: Implementasi, Strategi dan Inovasinya (1st ed.; T. Limbong, Ed.). Yayasan Kita Menulis. ISBN: 978-623-7645-13-9.

Sagita, M. (2018). Bisnis Budidaya Udang Vannamei di Era Revolusi Industri 4.0 - kumparan.com. https://kumparan.com/kumparanbisnis/bisnisbudidaya-udang-vannamei-di-era-revolusiindustri-4-0-1544718001094064799

Watie, E. D. S. (2016). Komunikasi dan Media Sosial (Communications and Social Media). Jurnal The Messenger, 3(2), 69. ISSN: 2086-1559. https://doi.org/10.26623/themessenger.v3i2.27 0

Yunianto, T. K. (2019). Menteri Edhy Dorong Produksi Udang Naik 2,5 Kali Lipat - Berita Katadata.co.id

https://katadata.co.id/berita/2019/12/16/menter i-edhy-dorong-produksi-udang-naik-25-kalilipat

Yusup, P. M., Komariah, N., Prahatmaja, N., \& CMS, S. (2019). Pemanfaatan Internet Untuk Penghidupan Di Kalangan Pemuda Pedesaan. Baca: Jurnal Dokumentasi Dan Informasi, 40(2), $217 . \quad$ ISSN: $0125-9008$. https://doi.org/10.14203/j.baca.v40i2.491 